UDK 811.16’342.41(091)

Izvorni znanstveni rad

Rukopis primljen 2. II. 2018.

Prihvaćen za tisak 26. IV. 2018.

\author{
Frederik Kortlandt \\ Leiden University \\ F.Kortlandt@hum.leidenuniv.nl \\ www.kortlandt.nl
}

\title{
RISE AND FALL OF VOWEL LENGTH IN SLAVIC
}

\begin{abstract}
My observation that Mate Kapović's ideas about Slavic accentuation lack a chronological perspective has evoked a furious reaction (Kortlandt 2016b: 478f., Kapović 2017). Since his account can easily leave a false impression on an uninitiated reader, I will here try to clarify the major issues in the simplest way possible. I will limit myself to the five topics that Kapović apparently found most difficult to appreciate: pretonic vowel length, the genitive plural, monosyllabic lengthening, length in medial syllables, and length in Czech monosyllables. The numbers of the stages mentioned below refer to the detailed relative chronology of Slavic phonological developments that I have proposed elsewhere (Kortlandt 1989, 2011: 157-176, 277-309).
\end{abstract}

1. The oldest type of long vowel in Balto-Slavic are Proto-Indo-European lengthened grade vowels, e.g. Lith. duktẽ 'daughter', akmuõ 'stone', Greek $\theta v \gamma \alpha \dot{\tau} \eta \rho, \not \alpha \kappa \mu \omega v, \mathrm{~S} / \mathrm{Cr}$. žërāv 'crane', sigmatic aorist 1st sg. dònijeh 'brought', ùmrijeh 'died', root nouns Lith. gèlà 'pain', žolée 'grass', mèsà 'meat', all (4), $\mathrm{S} / \mathrm{Cr}$. rïječ 'word', čâr 'magic', sâm 'alone', Czech čár, čára, sám (b). In principle, these long vowels were never shortened (cf. Kortlandt 1985, Vermeer 1992). The second oldest type of long vowel in Balto-Slavic developed from the loss of a laryngeal between two full vowels $\left({ }^{*} e,{ }^{*}\right.$ o), e.g. Lith. gen.sg. algõs

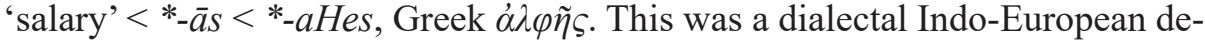
velopment which Balto-Slavic shared with Indo-Iranian, but not with Greek, where the circumflex points to a disyllabic sequence at an earlier stage of the language. Other long vowels originated in the separate branches of Balto-Slavic. At that time, the remaining laryngeals had merged into a glottal stop, e.g. 
Lith. algà (4) <*-a?, galvà (3) 'head' < *gol?wa? < *golHuaH, and the ProtoIndo-European glottalic consonants had dissolved into a laryngeal and a buccal part (Winter's law, stage 4.3 of my chronology), e.g. Latvian pệds $<{ }^{*} p e^{?} d o m$ 'footstep', nuôgs $<*^{\text {no }} \mathrm{g}^{w}$ os 'naked'.

In Slavic, glottalization was lost in pretonic and post-posttonic syllables with compensatory lengthening of an adjacent vowel (stage 5.3), e.g. *golwà? $<$ *gol?wà? 'head', *pīlà? < *p?ilà? '(she) drank', inst.sg. *sūnumi < *suPnumi 'son', *òpsnowa $<$ *òpsnowa? 'base', inst.pl. *gèna?mịs < *gèna?mi?ș 'women'. The long vowel in the final syllable of the latter words is reflected by the neo-circumflex tone of Slovene osnọva $<{ }^{*}$ osnòwā, ženâmi $<$ *ženàmī, where the middle syllable received the stress as a result of Dybo's law. Glottalization was eliminated by analogy in barytone forms of mobile accent paradigms (Meillet's law, stage 5.4), e.g. S/Cr. sîn 'son', acc.sg. glâvu, neuter pîlo, cf. Lith. gálvą, súnų. Glottalization was preserved in stressed and first posttonic syllables up to a later stage.

New long vowels originated from the monophthongization of diphthongs: $*_{\bar{e}}<* a i, *_{\bar{e}}<*_{e i}, *_{\bar{o}}<*_{a u}$ (stage 6.5 ). The rise of nasal vowels $*_{i N}, *_{e N}$, $*_{a N}, *_{o N}, * u N$ can be dated around the same time. The same holds for the rise of glottalized vowels $\dot{i}, \dot{e}, \dot{e}, \dot{a}, \dot{o}, \dot{u}$, which had the timbre of the corresponding long vowels, as in the case of the Latvian broken tone in $\hat{\imath}, i \hat{e}, \hat{e}, \hat{a}, u \hat{o}, \hat{u}$. At a later stage (7.8), the rounded vowels $* u, * \bar{u}, * u N$ and their glottalized counterparts were delabialized to $*_{y}, *_{\bar{y}}, *^{*} N$, after palatalized consonants $*_{i}, *_{\bar{i}}, *_{i N}$, and the long mid vowels $*_{\bar{e}}$ and ${ }^{*} \bar{o}$ were subsequently raised to ${ }^{*} \bar{i}$ and $*_{\bar{u}} \overline{\text { (sta- }}$ ge 7.9). This resulted in the following vowel system (cf. Kortlandt 2011: 106):
$\bar{l}$

$$
\begin{array}{llllllll}
\bar{e} & \bar{y} & \bar{a} & \bar{u} & e N & a N & o N
\end{array}
$$$$
\text { oN } \quad i
$$$$
\text { e } \quad y \quad a
$$

Here the long vowels and the nasal vowels could be either glottalized (acute) or not. In initial syllables, the non-acute vowels could be either falling (circumflex) or not.

At this stage (7.13), the loss of glottalization in posttonic syllables gave rise to a series of new short vowels $i, \check{e}, a, u, y$ which were opposed to the older short vowels $b, e, o, b$ by timbre and vowel height. The result is the following vowel system (cf. Kortlandt 2011: 107):

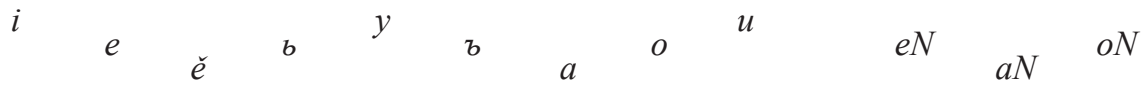


In stressed syllables, the acute vowels were now half-long while the nonacute vowels could be either long or short. In pretonic syllables, long vowels were shortened and the opposition between long and short vowels was replaced by the new timbre distinctions. In posttonic syllables, vowel length remained distinctive but final nasal vowels were shortened, e.g. S/Cr. nom.acc.pl. glâve with a short ending versus gen.sg. glávē $<*$-é 'head', Slovene gen.sg. kráve (a) 'cow' without neo-circumflex versus goré (c) 'mountain' with a long vowel, similarly Susak (Croatian) gen.sg. sestrè (b) 'sister' versus vodiè (c) 'water'. There is no trace of glottalization in final nasal vowels. The mid vowels $e, b, b$, $o$ were always short, but that was to change very soon when new long vowels originated from Van Wijk's law (stage 7.15), contractions in posttonic syllables (stage 8.1), the retraction of the stress from final jers (stage 8.2), and lengthening in monosyllables (stage 8.8).

In pretonic syllables, vowel length became distinctive when Dybo's law shifted the accent from non-acute vowels to the following syllable (stage 8.7), e.g. *nāròd ‘ 'people', *ōNtròbā 'entrails', Slovene národ, vótroba. Short falling vowels in monosyllables were lengthened (stage 8.8), e.g. S/Cr. bôg 'god', kôst 'bone', dân 'day'. The final loss of glottalization in stressed syllables gave rise to new short rising vowels (stage 9.2), e.g. Slovene dim 'smoke', góra < *gorà 'mountain'. The retraction of the stress from long falling vowels in final syllables (Stang's law, stage 9.3) yielded new long rising vowels. These developments were followed by lengthening of short rising vowels and shortening of long falling vowels under certain conditions and by the rise of new long falling vowels in Slovene.

Summarizing, we can say that in pretonic syllables long vowels originated from Dybo's law while in stressed and posttonic syllables long vowels continue Proto-Indo-European lengthened grade vowels and dialectal Indo-European contractions and arose from the Slavic monophthongization of diphthongs. After the rise of the new timbre distinctions, new long vowels resulted from Van Wijk's law and contractions in posttonic syllables, in accent paradigm (c) from the retraction of the stress from final jers and from lengthening in monosyllables, and in accent paradigm (b) from Stang's law.

2 . Thus, pretonic long vowels were shortened when the new timbre distinctions arose (7.13), e.g. S/Cr. màlina 'raspberry', jèzik 'tongue', svjèdok 'witness', dùžnīk 'debtor', mùškī 'man's'. New pretonic long vowels originated as a result of Dybo's law (8.7), e.g. S/Cr. zábava 'fun, party', Slovene zabâva, Czech zábava and similarly národ 'people', zákon 'law'. The latter were never shortened in Proto-Slavic. In Serbian and Croatian, pretonic length was re- 
stored in disyllabic word forms of accent pattern (c), e.g. nom.sg. rúka 'hand' on the analogy of acc.sg. rûku, nom.acc.pl. rûke, but not in polysyllabic word forms such as obl.pl. rùkama, similarly Čakavian (Hvar) rūkä, rûku, dat.loc. sg. rūcï, but gen.sg. ruké, inst.sg. rukón, pl. rûke, rúk, rukïma, cf. Czech ruka with a short vowel throughout the paradigm. The accent pattern remained distinct from that of S/Cr. trúba 'trumpet' (b), which has a long vowel throughout, like Czech trouba.

Kapović objects to the analogical restoration of length in S/Cr. rúka that the "supposed original **ùka $<* *$ rŭkä (or analogical **üku) is nowhere to be found in Štokavian /Čakavian /Kajkavian" (2017: 385). This is a typical example of his lack of chronological perspective. Of course, the restoration of vowel length took place between Dybo's law (stage 8.7), which reintroduced pretonic long vowels, and the shortening of long falling vowels (stage 9.4), which did not affect monosyllables and disyllabic word forms in Croatian. Similarly, vowel length was restored in Slovene dúša 'soul', zvẹzzda 'star', cẹna 'price', stẹna 'wall' (not "stone", thus Kapović 2017: 384) before the lengthening of the shortened acute (cf. Kortlandt 2011: 55-57). Kapović disregards the difference between accent paradigm (b), where pretonic long vowels arose from Dybo's law and did not alternate with short vowels, and accent paradigm (c), where pretonic long vowels had been shortened and alternated with long vowels in stressed and posttonic syllables.

The length of Czech trásti 'to shake' was taken from the l-participle trásl, where it had arisen from the retraction of the stress from the final jer (stage 8.2). The retraction of the stress in Czech kliti 'to swear' and mriti 'to die' was much earlier (stage 4.4), as it was in S/Cr. vïti 'to twist', grïsti 'to bite', sjëći 'to cut' (cf. Kortlandt 2011: 160-162, 314, 344f.). The short vowel in the Czech l-participles klel and mrel is the phonetic reflex of the Proto-Slavic falling tone (stage 9.4). Kapović's lack of understanding (2017: 384) is a consequence of his lack of chronological perspective. The restoration of pretonic length in Čakavian 2nd sg. trēsëš and 3rd sg. trēsë but not in 1st pl. tresemö and 2nd pl. tresetë (Kapović 2017: 387) is a consequence of the fact that pretonic length was limited to the first pretonic syllable.

Kapović's view that $\mathrm{S} / \mathrm{Cr}$. dëvet, dëset beside dëvēt 'nine', dësēt 'ten' are allegro forms (2017: fn. 11) may be correct, and the same holds for Czech devět, deset and Slovak devät', desat'. The oblique forms Czech deviti, desiti and Slovak deviati, desiati continue the barytone case forms, not the gen.sg. form (thus Kapović 2017: 385), which is attested in OCS desęte. Kapović's view that posttonic length is always shortened in accent paradigm (c) in West Slavic (2017: fn. 10) is quite unacceptable because posttonic long vowels were 
consistently preserved in accent paradigm (a), where they did not alternate with short vowels. Note that the sigmatic nom.sg. ending was stressed in mobile accent paradigms. Many words that originally belonged to accent pattern (a) adopted mobile stress at an early stage (cf. Kortlandt 2011: 342f.). Here again, Kapović's view is based on a lack of chronological perspective. The rise of accentual mobility in Russian lebed' 'swan' $<*$ lo- $<*$ ol- and Czech labut' with $l a-$, not lo-, can be dated after the rise of secondary mobility in words like $\mathrm{S} / \mathrm{Cr}$. $z \hat{u} b$ 'tooth' (stage 6.9) and after the rise of distinctive tone (stage 6.10) but before the early metathesis of liquids (stage 7.12) and before the shortening of long vowels in pretonic syllables (stage 7.13).

3. The short root vowel in the Old Polish infinitives sędzic 'to judge', przystępić 'to approach', żędać 'to demand' (Kapović 2017: 387) offers a serious problem for the theory that these verbs belong to accent paradigm (b). There are other verbs with an infinitive that belongs to a different accent class than the present and the $l$-participle, e.g. S/Cr. vïti 'to twist', which has an acute infinitive (a) but a mobile present and $l$-participle (c), also sjëći 'to cut', which has an acute infinitive and $l$-participle (a) but a mobile present (c), and pèć ' 'to bake', which has an end-stressed infinitive and $l$-participle (b) but a mobile present (c), and lèci 'to lie down', which has an acute present (a) but an end-stressed infinitive and $l$-participle (b). These aberrant patterns go back to Balto-Slavic times. The same holds for the difference between Polish sędzia 'judge' < *sodi?, which continues the Proto-Indo-European hysterodynamic flexion (cf. Kortlandt 2016a: 79), and sąd 'law court' < $s o ́ d b$. If sędzić is a denominative of * sodi?, not of $*_{s o ́} d b$, the expected reflex is the infinitive $*_{\text {soditi }}<*$-ii- and

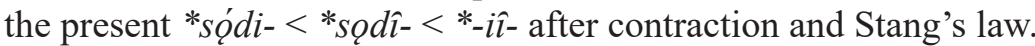

In the case of przystepic, the short root vowel is the expected reflex in compound verbs where Dybo's law shifted the stress from the prefix to the root, e.g. Čakavian (Kukljica) ugäsin beside gasîn 'turn off', with restoration of the long root vowel in prebûdin beside budin 'wake up'. It is probable that in compound verbs prefixal stress was original and was later replaced by the accentuation of the simplex. Other verbs show an apophonic alternation between infinitive and present stem that betrays an accentual difference at an early stage, e.g. OCS pbsati, piše- 'write', dbxati, duše- 'breathe' (replaced by dyxati, dyše-), which cannot represent a single accentual paradigm. It is therefore probable that Old Polish żędać never had initial stress, and the same may hold for the Slovincian verbs listed by Stang (1957: 42). ${ }^{1}$

1 Contrary to Kapović's claim (2017: 388), the different stem formations cannot be explained by a difference between dominant and recessive suffixes in the infinitive and the $l$-participle. Here again, his lack of chronological perspective manifests itself. 
4. Kapović still adheres to the outdated view that the Proto-Indo-European gen.pl. ending was $*_{-} \bar{o} m$, for which there is no evidence (cf. Kortlandt $1978 \mathrm{~b}$ and 2014). Retraction of the stress from final jers yielded a long vowel in mobile accent paradigms (stage 8.2), e.g. Slovene gen.pl. gọr < *gorb 'mountains', óvac < *owbcb 'sheep' (Ramovš 1921: 234), Polish rąk< * rokb 'hands'. The short vowel in Slovene nom.sg. kònj 'horse' shows that the accent was never retracted in this form and that the retraction of the stress in mobile paradigms preceded Dybo's law (stage 8.7). It follows that the length in gen.pl. kọnj is analogical after the mobile type. The original short root vowel in the gen.pl. forms has been preserved in Polish pęt 'fetters', btot 'swamps', Czech krav 'cows', dèl 'works', Slovincian làt 'years', jàgnjąt 'lambs', cieląt 'calves', as opposed to the long vowel in mjóun of imja 'name', votroč́ut of vùotroča 'child' (I use a simplified variant of Lorentz's 1903 transcription), Ukrainian kolód 'logs' $<* k o l o d b<* k o ̉ l d b$ as opposed to boríd 'beards' < *boród $b<*$ bordţ. The long vowel in the gen.pl. forms was generalized in South Slavic (cf. Kortlandt 1978b: 285). The S/Cr. ending $-\bar{a}$ does not continue an original long jer but was introduced on the analogy of the loc.pl. ending of the $i$ - and $u$-stems (cf. Stevanović 1933: 67, ${ }^{2}$ with reference to Belić, and Kortlandt 1978b: 286).

5. According to Kapović (2017: 391), there is "no point in reconstructing **bogz instead of *bögz" and "this imaginary **bogg would have yielded the same reflex as *bögz everywhere". This is again an instance of his lack of chronological perspective. When Dybo's law shifted the stress to the following syllable (stage 8.7) yielding long falling vowels in opposition to short and long rising vowels in non-initial syllables, the tonal opposition on short vowels became limited to monosyllables, e.g. *bögъ versus *kònjb. This anomalous distribution was resolved by lengthening short falling vowels in monosyllables (stage 8.8), resulting in the same opposition between short and long rising versus long falling vowels that existed in non-initial syllables, e.g. Slovene bôg, kònj, gen.pl. gọ́r. The loss of glottalization in acute syllables (stage 9.2) yielded new short rising vowels in all positions, after which long falling vowels in non-initial syllables were eliminated by Stang's law (stage 9.3) and the remaining long falling vowels were shortened in West and East Slavic (stage 9.4). The length in S/Cr. göspōd 'lord', kökōt 'rooster', kökōš 'hen', mlädōst 'youth', bölēst 'illness', gövōr 'speech', körēn 'root', plämēn 'flame', jäblān 'poplar' beside göspod, kökot, kökoš, mlädost, bölest, gövor, kören, plämen, jäblan is a more recent development of analogical origin that did not reach all $\mathrm{S} / \mathrm{Cr}$. dialects and has nothing to do with the lengthening in bôg.

2 Pretpostavka Rešetarova, da je ovaj nastavak vokalizovan stari nastavak genitiva množine, neosnovana je, jer je apsolutno nemoguće da se poluglasnik sačuva u poziciji u kojoj se, kao nekadašnji nastavak gen. množ., nalazio." 
6. Long falling vowels in medial syllables that arose from Dybo's law and did not lose the stress in accordance with Stang's law were shortened, e.g. S/

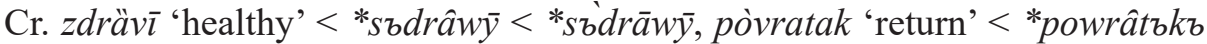
$<$ *pòwrātıkъ, záslužan 'deserving' < *zāslûžbnъ < *záslūžbnъ, zgräda 'building' < * sbgrâda $<*_{\text {sb̆grāda }}$, Slovene zgrâda (with neo-circumflex). Kapović reconstructs "simple *sъdörvъjb, *povörtъkъ, *zaslüžbnъ, *sъgörda (with the generalized, non-etymological old acute typical in prefixed derivatives and compounds)" (2017: 394f.) without explaining the origin of the "non-etymological old acute", which simply means a shortened long vowel. Thus, his account is equivalent to mine except for the fact that he lacks the chronological perspective and does not explain the Slovene neo-circumflex. He reconstructs Slovak pýta $<{ }^{*}$ py tâ $<$ *pytäje without explaining the long vowel and the difference between Čakavian pĩtā 'asks' and kopâ 'digs', Bulgarian píta versus kopáe, Old Polish kopaje. The difference is explained by the early contractions in posttonic syllables (stage 8.1), e.g. *pȳtâ $<{ }^{*} p y t a \bar{a}<*$ pytaje, as opposed to original *kopäje. He objects to my formulation of Stang's law that the accent should not have been retracted in the 1st and 2nd pl. forms (2017: fn. 31). In fact, the expected accentuation is found in Carpathian (Ublja) byváu $u$, bývaš, bývat', byváieme, byváiete, byváu' (Broch 1900: 106), with restoration of the thematic vowel in *-à(e)me, *-à(e)te on the analogy of *kopà(j)e-. Kapović's "most important arguments" against Stang's law (2017: fn. 22) have adequately been refuted in the literature (cf. Vermeer 1984, Kortlandt 2011: 37-39 and 2012b).

Kapović thinks that the long vowel in such cases as Čakavian črnina 'blackness', ravnic a 'plane', dvorĩśce 'courtyard' contradicts my theory. This is again a result of his lack of chronological perspective. Vowel length in derivational suffixes is mostly generalized, e.g. $\mathrm{S} / \mathrm{Cr}$. $-a t,-a v,-i c a$, $-i n a$ versus $-\bar{a} r$, -ikk, -inn, -ina (cf. Dybo 1968). Original differences have been preserved e.g. in dvòrište (b) 'yard' versus blätǐšte (a) 'mud-pit' and Czech pekař (c) 'baker' versus rybár (a) 'fisherman' (cf. Kortlandt 2011: 266). In compounds, too, Kapović sees "a tendency to generalize the old acute" on non-acute long vowels (2017: 396) without giving an explanation, e.g. in S/Cr. golobrad 'barefaced'

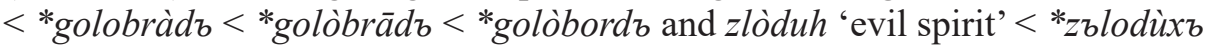
$<*_{z b l o d u ̄ x z}$. This accentuation is in agreement with Vedic ugrábāhus 'with strong arms', viśvárūpas 'omniform', sahávatsā 'accompanied by her calf'.

7. Elsewhere I have argued that the long vowel in Czech kưn̆ 'horse', stůl 'table', nůž 'knife', Slovak kôň, stôl, nôž, also bôb 'bean', kôš 'basket' (Old Czech kóś), kôpor 'dill', vôdor 'hay-loft' did not arise phonetically but was adopted from the case forms where the accent had been retracted in accordance with Stang's law before the loss of weak jers, the shortening of long falling 
vowels in initial syllables, the loss of distinctive tone, and the fixation of the stress on the initial syllable (Kortlandt 2011: 345f., cf. Verweij 1994: 556f.).

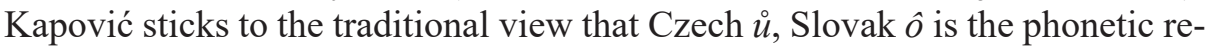
flex of $* \dot{o}$ in monosyllables (2017: 397), which does not explain the short vowel in Czech osm, Slovak osem 'eight' < *òsmb. His treatment again lacks a chronological perspective.

I conclude that in spite of his overwhelming rhetoric, Kapović's diatribe has not produced any new insights but only revealed the paucity of his conceptual framework.

8. The most important result of Stang's analysis is that the Slavic accent patterns must not be derived from inherent tonal properties of their constituents but, conversely, that the tones must be derived from the accent patterns (1957: 179). Stang showed that the acute is characteristic of paradigms with fixed stress (a), that the neo-acute developed from a retraction of the stress in paradigm (b), and that the circumflex is characteristic of paradigms with mobile stress between initial and final syllables (c). Dybo has shown that paradigm (b) developed from a paradigm with fixed stress as a result of an accent shi$\mathrm{ft}$ from a non-acute vowel to a following syllable $(1962,1968)$. Since paradigms (a) and (b) are in complementary distribution, they can be identified with the Lithuanian accent patterns (1) and (2). The backbone of my own theory is the thesis that the Balto-Slavic acute was a glottal stop which developed from the Indo-European laryngeals and from Winter's law and is reflected as glottalization in Latvian and Lithuanian, and that the gradual loss of this glottal stop accounts for the development of vocalic timbre and quantity distinctions in Slavic. The red thread which runs through these developments is a series of sound changes: Hirt's law (4.1), Winter's law (4.3), retraction of the stress from final open syllables (4.4), loss of the glottal stop in pretonic and post-posttonic syllables (5.3), loss of the glottal stop in the remaining posttonic syllables (7.13), Van Wijk's law (7.15), contractions in posttonic syllables (8.1), retraction of the stress from final jers (8.2), Dybo's law (8.7), lengthening of short falling vowels in monosyllables (8.8), loss of glottalization in stressed syllables (9.2), Stang's law (9.3), shortening of long falling vowels (9.4), lengthening of short vowels and retractions of the stress in the daughter languages (10.4-10.12). These phonetic laws were followed by analogical levelings which account for the distribution of accent, timbre and quantity in the attested Slavic material.

The Moscow accentological school has abandoned Dybo's law and Stang's law and returned to the pre-1957 derivation of accent patterns from reconstructed tonal properties of their constituents (cf. Hendriks 2003). According to the 
revised doctrine, "high (dominant) and low (recessive) tones" would "have coexisted with the traditional prosodemes (the acute, the circumflex, and the neo-acute - though these can be interpreted in various ways, e.g. as prosodic glottalization, lack of phonological stress, and the non-glottalized stress)" (Kapović 2017: fn. 21). Since I have criticized this theoretical framework earlier (1978a, 2011: 75-86, 135-146, 241-243), there is no reason to return to the matter here. Attempts to solve classic problems in terms of dominance patterns have resulted in complete failure (e.g. Oslon 2011, cf. Kortlandt 2012a). There is simply no viable alternative to the theory of Slavic accentuation that I proposed 45 years ago.

\section{References:}

Broch, Olaf. 1900. Ugrorusskoe narěčie sela Ubli. Tipografija Imperatorskoj Akademii Nauk. Sankt-Peterburg.

Dyвo, Vladimir A. 1962. O rekonstrukcii udarenija v praslavjanskom glagole. Voprosy slavjanskogo jazykoznanija 6. 3-27.

Dybo, Vladimir A. 1968. Akcentologija i slovoobrazovanie v slavjanskom. Slavjanskoe jazykoznanie: VI meždunarodnyj sъezd slavistov. Nauka. Moskva. 148-224.

Garde, Paul. 1976. Histoire de l'accentuation slave. Institut d'études slaves. Paris.

Hendriks, PePIJn. 2003. A note on Stang's law in Moscow accentology. Dutch contributions to the 13th international congress of Slavists: Linguistics. Rodopi. Amsterdam. 107-123.

KAPOVIĆ, MATE. 2017. On shortening, lengthening, and accent shifts in Slavic. Rasprave Instituta za hrvatski jezik i jezikoslovlje 43/2. 381-402.

Kortlandt, Frederik. 1978a. A history of Slavic accentuation: Review of Garde 1976. Lingua 44. 67-91.

Kortlandt, Frederik. 1978b. On the history of the genitive plural in Slavic, Baltic, Germanic, and Indo-European. Lingua 45. 281-300.

Kortlandt, Frederik. 1985. Long vowels in Balto-Slavic. Baltistica 21/2. 112-124.

Kortlandt, Frederik. 1989. Od praindoevropskog jezika do slovenskog (fonološki razvoj). Zbornik za Filologiju i Lingvistiku 32/2. 41-58.

KortlandT, Frederik. 2011. Selected writings on Slavic and general linguistics. Rodopi. Amsterdam.

Kortlandt, Frederik. 2012a. Dominance and monophthongization: method versus insight. Baltistica 47/2. 255-259. 
KortLANDT, Frederik. 2012b. The Slovene neo-circumflex revisited. Rasprave Instituta za hrvatski jezik i jezikoslovlje 38/1. 117-122.

KortLANDT, FrEDERIK. 2014. Reconstructing Balto-Slavic and Indo-European. Baltistica 49/1. 5-13.

Kortlandt, FrederiK. 2016a. Slavic $i$-verbs, imperfect, and $j \bar{a}$-stem nouns. Rasprave Instituta za hrvatski jezik i jezikoslovlje 42/1. 75-81.

Kortlandt, Frederik. 2016b. On the rise of neo-acute $*^{*}$ and ${ }^{*}$ o. Rasprave Instituta za hrvatski jezik i jezikoslovlje 42/2. 471-482.

LORENTZ, FrIEDRICH. 1903. Slovinzische Grammatik. Tipografija Imperatorskoj Akademii Nauk. Sankt-Peterburg.

Oslon, MixaIL V. 2011. Raspredelenie diftongov ei $\sim$ ie v litovskom jazyke. Baltistica 7. 133-170.

Ramovš, Fran. 1921. O slovenskem novoakutiranem o. Južnoslovenski Filo$\log 2.227-239$.

StAng, Christian S. 1957. Slavonic accentuation. Universitetsforlaget. Oslo.

Stevanović, Minailo S. 1933. Istočnocrnogorski dijalekat. Južnoslovenski Filolog 13. 1-128.

VERMEER, WILlEM R. 1984. On clarifying some points of Slavonic accentology: The quantity of the thematic vowel in the present tense and related issues. Folia Linguistica Historica 5/2. 331-395.

VermeER, WiLLEM R. 1992. In the beginning was the lengthened grade: On the continuity of Proto-Indo-European vowel quantity in Slavic. Rekonstruktion und relative Chronologie: Akten der VIII. Fachtagung der Indogermanischen Gesellschaft, Leiden, 1987. Institut für Sprachwissenschaft. Innsbruck. 115-136.

VerweIJ, ARno. 1994. Quantity patterns of substantives in Czech and Slovak. Dutch contributions to the 11th international congress of Slavists: Linguistics. Rodopi. Amsterdam. 493-564.

\section{Nastanak i nestanak vokalskih dužina u slavenskom}

\section{Sažetak}

Moja opaska da viđenju Mate Kapovića o slavenskoj akcentologiji nedostaje kronološka perspektiva izazvala je burnu reakciju. Ovdje se ograničujem na pet tema koje mu je očigledno bilo najteže uzeti u obzir: prednaglasnu dužinu, genitiv množine, duljenje jednosložnih riječi, dužinu u srednjim slogovima i dužinu u češkim jednosložnicama. Unatoč svojoj snažnoj retorici Kapovićeva 
dijatriba nije donijela nov uvid, nego je samo pokazala slabost njegova konceptualnog okvira. Nema održive alternative teoriji slavenske akcentuacije koju sam predložio prije 45 godina.

Ključne riječi: akcentuacija, vokalska dužina, slavenski

Keywords: accentuation, vowel length, Slavic 
